\title{
SOIL ACIDITY, LIMING AND SOYBEAN PERFORMANCE UNDER NO-TILL
}

\author{
Eduardo Fávero Caires ${ }^{1 *}$; Gabriel Barth²; Fernando José Garbuio²; Susana Churka² \\ ${ }^{1} U E P G$ - Depto. de Ciência do Solo e Engenharia Agrícola - 84030-900 - Ponta Grossa, PR - Brasil. \\ ${ }^{2}$ ESALQ/USP - Programa de Pós-Graduação em Solos e Nutrição de Plantas, C.P. 09 - 13418-900 - Piracicaba, \\ SP - Brasil. \\ *Corresponding author <efcaires@uepg.br>
}

\begin{abstract}
The effects of soil chemical changes on soybean root growth, mineral nutrition and grain yield, as a result of surface application of lime under no-till (NT), are still under discussion. A field trial was carried out on a loamy dystrophic Typic Hapludox at Ponta Grossa, Paraná State, Brazil, using a completely randomized block design with three replicates, in a split-plot experiment. The main plots received four dolomitic lime rates applied on the surface $\left(0,2,4\right.$, and $\left.6 \mathrm{Mg} \mathrm{ha}^{-1}\right)$ in July 1993 . In the subplots, two dolomitic lime rates were reapplied on the surface $\left(0\right.$ and $\left.3 \mathrm{Mg} \mathrm{ha}^{-1}\right)$ in June 2000 . After nine years, liming increased $\mathrm{pH}$, exchangeable $\mathrm{Ca}^{2+}$ and reduced exchangeable $\mathrm{Al}^{3+}$ as well as soil $\mathrm{Al}^{3+}$ saturation down to a $60 \mathrm{~cm}$ depth. Re-liming, after two years, also provided soil acidity amelioration to a $60 \mathrm{~cm}$ depth. Soybean total root length per soil surface area $(0-60 \mathrm{~cm})$ decreased with the surface lime application under NT. The reduction in soil exchangeable $\mathrm{Al}^{3+}$ with liming did not change $\mathrm{Al}$ concentrations in the soybean roots and leaves. Surface-applied dolomitic lime under NT brought an increase in $\mathrm{Ca}$ and $\mathrm{Mg}$ concentrations and a decrease in the $\mathrm{Mn}$ level in both soybean roots and leaves. Soybean grain yield was not influenced by surface liming because of the decreased Al toxicity and because root growth was stimulated by soil acidity stress under NT.
\end{abstract}

Key words: Glycine $\max (\mathrm{L}$.$) Merrill, acidity, subsoil, root system, nutrient$

\section{ACIDEZ DO SOLO, CALAGEM E COMPORTAMENTO DA SOJA CULTIVADA EM PLANTIO DIRETO}

\begin{abstract}
RESUMO: Os efeitos das alterações químicas do solo ocasionadas pela aplicação superficial de calcário no crescimento radicular, na nutrição mineral e na produção de grãos de soja cultivada em sistema plantio direto são pouco conhecidos e foram estudados no presente trabalho. $\mathrm{O}$ experimento foi realizado em um Latossolo Vermelho distrófico textura média, em Ponta Grossa (PR). O delineamento experimental empregado foi o de blocos completos ao acaso em parcelas subdivididas, com três repetições. As parcelas receberam quatro doses de calcário dolomítico na superfície $\left(0,2,4\right.$ e $\left.6 \mathrm{Mg} \mathrm{ha}^{-1}\right)$, em julho de 1993, e, nas subparcelas, foram reaplicadas duas doses de calcário dolomítico na superfície (0 e $\left.3 \mathrm{Mg} \mathrm{ha}^{-1}\right)$, em junho de 2000. A calagem, após nove anos, aumentou o $\mathrm{pH}$ e o $\mathrm{Ca}^{2+}$ trocável e reduziu o $\mathrm{Al}^{3+}$ trocável e a saturação por alumínio do solo, até a profundidade de $60 \mathrm{~cm}$. A reaplicação de calcário, após dois anos, também proporcionou melhoria nas condições de acidez do solo até a profundidade de $60 \mathrm{~cm}$. O comprimento total de raízes de soja por unidade de área superficial de solo $(0-60 \mathrm{~cm})$ foi reduzido com a calagem na superfície em plantio direto. A redução de $\mathrm{Al}^{3+}$ trocável no solo com a calagem não alterou as concentrações de Al nas raízes e nas folhas de soja. O calcário dolomítico aplicado na superfície em plantio direto aumentou as concentrações de $\mathrm{Ca}$ e $\mathrm{Mg}$ e reduziu o teor de Mn nas raízes e nas folhas de soja. A produção de grãos de soja não foi influenciada pela calagem na superfície por causa da baixa toxicidade do Al e ainda porque o crescimento radicular foi estimulado por condições de stress de acidez do solo no sistema plantio direto.

Palavras-chave: Glicyne max (L.) Merrill, acidez, subsolo, sistema radicular, nutrientes
\end{abstract}

\section{INTRODUCTION}

Brazilian soils are, on its majority, acidic with $\mathrm{Al}$ and Mn toxic levels, low base saturation and low $\mathrm{P}$ content (Olmos \& Camargo, 1976). Under such conditions crop root growth is restricted, causing lower water and nutrient uptake, affecting aerial development
(Pavan et al., 1982; Ritchey et al., 1982) and leading towards lower grain production.

Soil acidity problems are commonly corrected by applying limestone. To control soil acidity under notill (NT), lime is broadcast on the surface without incorporation. Surface liming ameliorates topsoil acidity in a relatively short term, but is generally slow in ame- 
liorating subsoil acidity, particularly in variable charge soils (Ernani et al., 2004). The movement of lime to greater depths varies according to the timing and rate of liming, soil type, surface soil $\mathrm{pH}$, weather conditions, management of acidic fertilizers, and cropping systems (Oliveira \& Pavan, 1996; Gascho \& Parker, 2001; Conyers et al., 2003; Ernani et al., 2004; Alleoni et al., 2005; Caires et al., 2005).

Field studies have attested high soybean yield in acid soils under NT (Caires et al., 1998, 1999, 2003, 2006a; Pöttker \& Ben, 1998; Moreira et al., 2001), but the causes still remain unclear. The explanations for this have been associated to decreased Al toxicity through the formation of Al-organic complexes (Salet et al., 1999; Nolla \& Anghinoni, 2006), sufficient availability of exchangeable $\mathrm{Ca}^{2+}$ and $\mathrm{Mg}^{2+}$ (Caires et al., 1998), and adequate nutrient uptake by the crop due to higher soil water availability (Caires \& Fonseca, 2000). However, soil acidity limited wheat root growth and yield severely under NT, probably as a result of extended water deficits during the vegetative stage (Caires et al., 2006b).

This study evaluated the effects of amelioration of topsoil and subsoil acidity by surface liming and re-liming in a NT system on root growth, nutrient and $\mathrm{Al}$ concentrations in roots and leaves, and grain yield of soybean grown without rainfall limitation.

\section{MATERIAL AND METHODS}

The experiment was carried out in Ponta

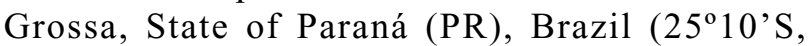
$50^{\circ} 05^{\prime} \mathrm{W}$ ), on a loamy dystrophic Typic Hapludox. At the beginning of the experiment, soil chemical and texture analyses of the $0-20 \mathrm{~cm}$ layer presented the following results: $\mathrm{pH}$ (1:2.5 soil: $0.01 \mathrm{~mol} \mathrm{~L}^{-1} \mathrm{CaCl}_{2}$ suspension) of 4.5; exchangeable $\mathrm{Al}^{3+}, \mathrm{Ca}^{2+}, \mathrm{Mg}^{2+}$, and $\mathrm{K}^{+}$ contents of $6,16,10$, and 1.4 mmolc $\mathrm{dm}^{-3}$, respectively; total acidity $\mathrm{pH} 7.0(\mathrm{H}+\mathrm{Al})$ of $58 \mathrm{mmolc} \mathrm{dm}^{-3}$; $\mathrm{P}$ (Mehlich-1) of $9.0 \mathrm{mg} \mathrm{dm}^{-3}$; total organic matter of $33 \mathrm{~g} \mathrm{dm}^{-3}$; base saturation of $32 \%$; $\mathrm{Al}^{3+}$ saturation of $18 \%$; and 295,240 , and $465 \mathrm{~g} \mathrm{~kg}^{-1}$ of clay, silt, and sand, respectively. Prior to the establishment of the experiment, the field site had been used for grain cropping under NT cultivation during 15 years.

A randomized complete block design was used, with three replications in a split-plot arrangement. The main plots $(8.0 \mathrm{~m} \times 6.3 \mathrm{~m})$ consisted of surface dolomitic lime application at the rates of 0,2 , 4 , and $6 \mathrm{Mg} \mathrm{ha}^{-1}$. The lime rates were calculated to raise the base saturation of the topsoil $(0-20 \mathrm{~cm})$ to 50,70 , and $90 \%$. The dolomitic lime used contained $176 \mathrm{~g} \mathrm{~kg}^{-1} \mathrm{Ca}, 136 \mathrm{~g} \mathrm{~kg}^{-1} \mathrm{Mg}$, and 84\% effective calcium carbonate equivalent (ECCE), and was broadcast on the soil surface in July 1993. In June 2000, the main plots were divided in two subplots $(4.0 \mathrm{~m} \times 6.3$ $\mathrm{m})$ for the study of surface re-liming influence (196 $\mathrm{g} \mathrm{kg}^{-1} \mathrm{Ca}, 130 \mathrm{~g} \mathrm{~kg}^{-1} \mathrm{Mg}$, and 90\% ECCE) at the rates of 0 and $3 \mathrm{Mg} \mathrm{ha}^{-1}$. The reapplied rate was calculated to raise the base saturation in the topsoil $(0-20 \mathrm{~cm})$ to $65 \%$ (Caires et al., 2000) of the treatment $4 \mathrm{Mg}$ $\mathrm{ha}^{-1}$ of lime made in July $1993\left(\mathrm{pH} 0.01 \mathrm{~mol} \mathrm{~L}^{-1} \mathrm{CaCl}_{2}\right.$ of 4.6; CEC pH 7.0 of $110.8 \mathrm{mmolc} \mathrm{dm}^{-3}$; and $41 \%$ of base saturation). More details about the experimental area and cropping history are reported in Caires et al. (2006b).

Soybean, cv. CD 206, was sown on November $21^{\text {st }}, 2001$ and November $12^{\text {th }}, 2002$, after growing black oats during the autumn-winter season, at a seeding rate of 16 seeds $\mathrm{m}^{-1}$ and row spacing of 0.45 $\mathrm{m}$. Seeds were inoculated with selected kinds of Bradyrhizobium japonicum. Fertilizers were applied at the rates of $220 \mathrm{~kg} \mathrm{ha}^{-1}$ of 2-20-20 and 0-25-25 (N$\mathrm{P}_{2} \mathrm{O}_{5}-\mathrm{K}_{2} \mathrm{O}$ ), on the first and the second sowings, respectively. During the development cycle of the soybean crop, rainfall was $770 \mathrm{~mm}$ in 2001-2002 and 880 $\mathrm{mm}$ in 2002-2003, well-distributed over both years. The average air temperature of both soybean cropping seasons was of $22^{\circ} \mathrm{C}$.

Samples of soybean leaves and roots were collected at the beginning of flowering. The third leaf from the apices of the plants was collected from 30 plants of each subplot. Samples of roots were collected by means of a sampling tube of $3.5 \mathrm{~cm}$ diameter, at the depths of $0-10,10-20$, and $20-60 \mathrm{~cm}$. Six subsamples of roots (three from the sowing row and three between rows) were taken in the subplot to form a composite sample. The roots were separated from the soil by dispersion in water using a $0.5 \mathrm{~mm}$ mesh sieve. Root length was estimated by the method of Tennant (1975), in a $1 \times 1 \mathrm{~cm}$ grid. The concentrations of $\mathrm{N}, \mathrm{P}, \mathrm{K}, \mathrm{Ca}, \mathrm{Mg}, \mathrm{S}, \mathrm{Zn}, \mathrm{Mn}$, and $\mathrm{Al}$ in soybean leaves and roots were analyzed through the methods described by Malavolta et al. (1997). After maturation, the soybean grain was harvested from $6.75 \mathrm{~m}^{2}$ plots (middle six rows of $2.5 \mathrm{~m}$ length). Grain yield was expressed at the $130 \mathrm{~g} \mathrm{~kg}^{-1}$ moisture content.

Soil samples were taken after soybean harvest in 2002 with a tubular probe sampler. Twelve soil core samples per subplot were taken to constitute a composite sample at $0-5,5-10$, and $10-20 \mathrm{~cm}$ depths, and five cores at 20-40, and 40-60 cm depths. Soil $\mathrm{pH}$ was determined in a $0.01 \mathrm{~mol} \mathrm{~L}^{-1} \mathrm{CaCl}_{2}$ suspension (1:2.5 soil/solution, v/v). Exchangeable $\mathrm{Al}^{2+}, \mathrm{Ca}^{2+}$, and $\mathrm{Mg}^{2+}$ were extracted with neutral $1 \mathrm{~mol} \mathrm{~L}^{-1} \mathrm{KCl}$, and $\mathrm{K}^{+}$with double acid (Mehlich-1), in a 1:10 (v/v) soil/ solution ratio, according to standard methods (Pavan et al., 1992). Exchangeable $\mathrm{Al}^{3+}$ (KCl-exchangeable 
acidity) was determined by titrating with $0.025 \mathrm{~mol} \mathrm{~L}^{-1}$ $\mathrm{NaOH} ; \mathrm{Ca}^{2+}$ and $\mathrm{Mg}^{2+}$ by titrating with $0.025 \mathrm{~mol} \mathrm{~L}^{-1}$ EDTA; and $\mathrm{K}^{+}$by flame photometry. The effective cation exchange capacity (ECEC) was calculated by summation of exchangeable cations, and the aluminum saturation as: $\mathrm{Al}^{3+}$ saturation $=100\left(\mathrm{Al}^{3+} / \mathrm{ECEC}\right)$.

Results were submitted to variance and polynomial regression analyses. Regression equations were adjusted to the obtained data according to lime rates, adopting as criterion for model choice the regressions with coefficients significant at 5\%. The effects of reliming were compared through the F-test.

\section{RESULTS AND DISCUSSION}

The variance analysis of the results of soil chemical attributes has shown significant interaction between lime rates and re-liming for $\mathrm{pH}$ and exchangeable $\mathrm{Ca}^{2+}$ at $0-5 \mathrm{~cm}$ depth, and for exchangeable $\mathrm{Al}^{3+}$ and $\mathrm{Al}^{3+}$ saturation at $0-5,5-10,10-20$, and $20-40 \mathrm{~cm}$ depths. The absence of interaction on the other depths demonstrated that the effects of the lime rates were equal for absence or presence of surface re-liming.

Surface-applied lime rates and re-liming on the surface after nine and two years respectively, increased soil $\mathrm{pH}$ and the exchangeable $\mathrm{Ca}^{2+}$ level over the five depths (Figure 1). Such increases occurred in a more expressive way in the soil surface layer $(0-5 \mathrm{~cm})$, mainly for the plots submitted to surface re-liming.

Exchangeable $\mathrm{Al}^{3+}$ and $\mathrm{Al}^{3+}$ saturation levels decreased in the five depths, according to lime rates as well as re-liming on the surface, after nine and two years respectively (Figure 2). Liming in 2000 on the previously no limed plots lead to an accentuated reduction in the exchangeable $\mathrm{Al}^{3+}$ and $\mathrm{Al}^{3+}$ saturation levels to a $40 \mathrm{~cm}$ depth. Due to this, the slope of the adjusted equations for the liming rates in 1993 was lower with the re-liming in 2000.

Similar effects of amelioration of topsoil and subsoil acidity by surface liming under NT have been obtained in other studies (Oliveira \& Pavan, 1996; Caires et al., 2000). A relatively fast effect of the surface re-liming on soil acidity neutralization to a $20 \mathrm{~cm}$ depth, after only nine months, was observed by Caires et al. (2000). In the present study the effects of amelioration of soil acidity by surface re-liming were observed in almost all soil profiles after two years.

The liming residual effect varies according to the soil acidity level, rate and type of lime, soil type, management of acidic fertilizers, and cropping systems (Oliveira \& Pavan, 1996; Gascho \& Parker, 2001; Conyers et al., 2003; Caires et al., 2005). In a field trial conducted on a sandy soil under NT (Rheinheimer et al., 2000), very little change on the exchangeable
$\mathrm{Al}^{3+}, \mathrm{Ca}^{2+}$, and $\mathrm{Mg}^{2+}$ contents was observed nine years after surface lime application compared with the liming initial effect. Azevedo et al. (1996) found that soil $\mathrm{pH}$ and exchangeable $\mathrm{Ca}^{2+}$ and $\mathrm{Mg}^{2+}$ contents remained high, and the exchangeable $\mathrm{Al}^{3+}$ level was low, for over 23 years after liming on a clayey soil with high organic matter content.

In the NT systems the addition of correctives, fertilizers, and vegetable residues on the soil surface occurs frequently. This implies in modifications of soil chemical, physical, and biological attributes, in comparison to the conventional tillage system. The following mechanisms might be involved in the amelioration of the subsoil acidity by surface liming under NT: (i) formation and migration of $\mathrm{Ca}\left(\mathrm{HCO}_{3}\right)_{2}$ and $\mathrm{Mg}\left(\mathrm{HCO}_{3}\right)_{2}$ to deeper soil layers (Costa, 2000); (ii) moving of exchangeable $\mathrm{Ca}^{2+}$ and $\mathrm{Mg}^{2+}$, and reduction of exchangeable $\mathrm{Al}^{3+}$ in the subsoil by formation of water soluble organic complexes present in plant residues (Franchini et al., 1999; Miyazawa et al., 2002); (iii) displacement of fine lime particles downwards in the soil profile with the water infiltration as a result of a soil aggregation amelioration due to increased organic carbon under NT (Amaral et al., 2004) and (iv) transportation of lime by the activity of soil biological agents, specially of those from the macrofauna (Silva et al., 1997; Chan, 2003). Regardless of the mechanism involved, the results revealed that surface liming was effective in alleviating the topsoil and subsoil acidity, showing long-term effect in this NT system.

The interaction between lime rates and re-liming was not significant for none of the attributes evaluated in the plant. This was the reason for the separate analyses of the soybean crops due to lime rates and re-liming.

Soybean total root length per soil surface area down to the depth of $60 \mathrm{~cm}$ was linearly reduced with liming rates, independently of surface re-liming (Figure 3). On the contrary of observations carried out in acid solutions (Sanzonowicz \& Smyth, 1995; Sanzonowicz et al., 1998), soybean root growth was stimulated by soil acidity stress under NT. An aspect which has been slightly underestimated over soil acidity in NT system studies is the presence of $\mathrm{H}^{+}$ion as a component of acidity. In this study, the majority of acidity was caused by $\mathrm{H}^{+}$and the soil had high organic carbon content. An increasing of the $\mathrm{H}^{+}$activity might have caused the change of the negative charges of the cellular walls and favored root elongation (Moloney et al., 1981), once there were proper soil moisture conditions. Soil $\mathrm{Al}^{3+}$ saturation of the no lime plots was $20 \%$ at the surface layer $(0-5 \mathrm{~cm})$ and $30 \%$ at deeper layers (Figure 2). The grown soybean cultivar is moderately susceptible to Al. Muzilli et al. (1978) reported 


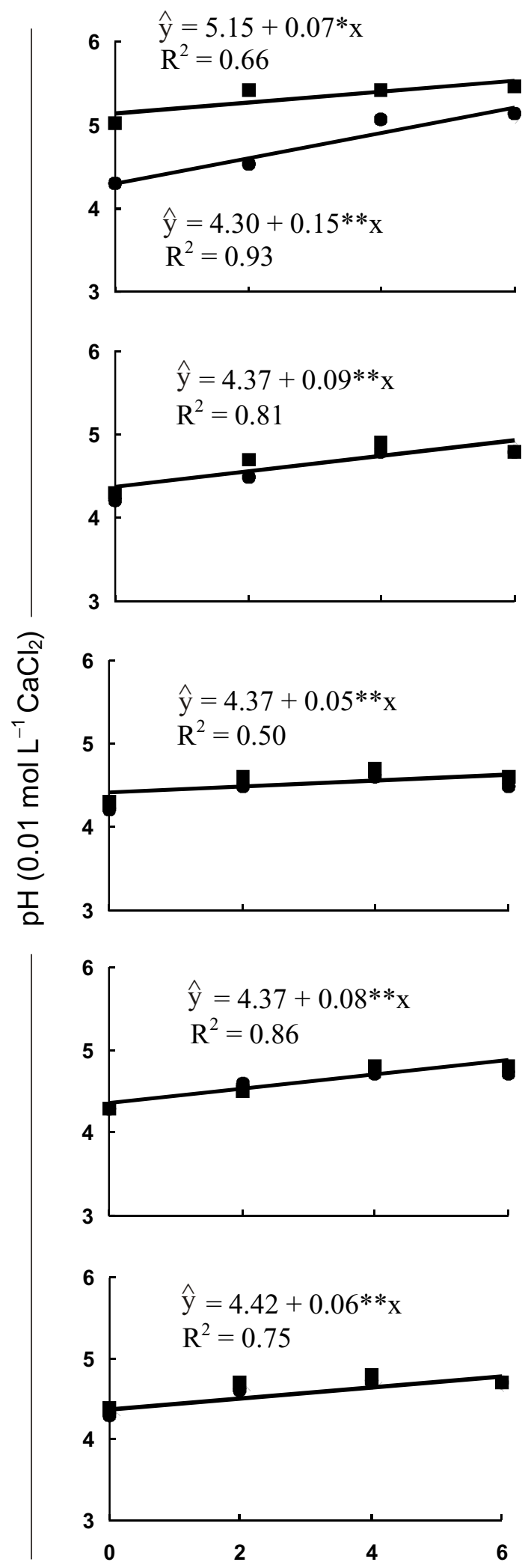

(a)

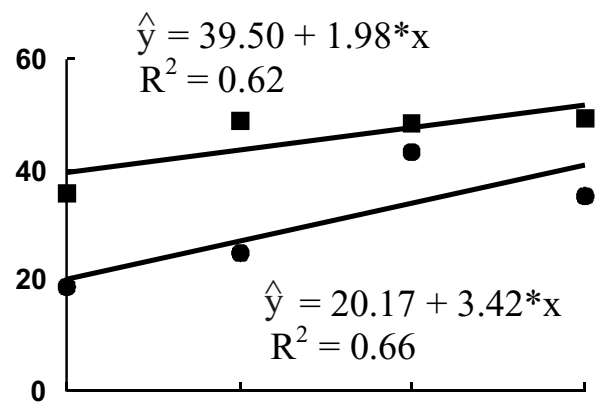

(b)

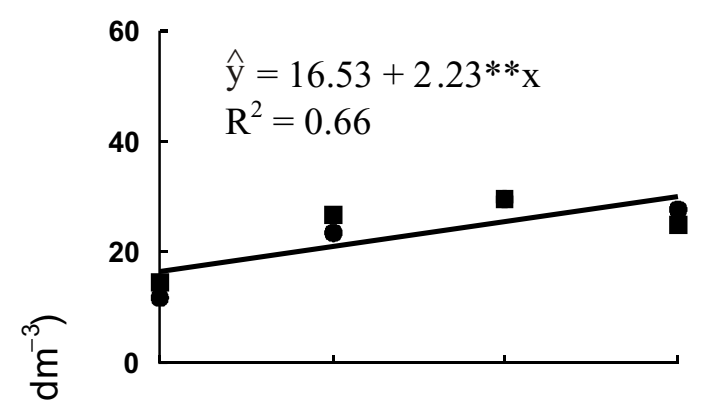

(c)

(d)
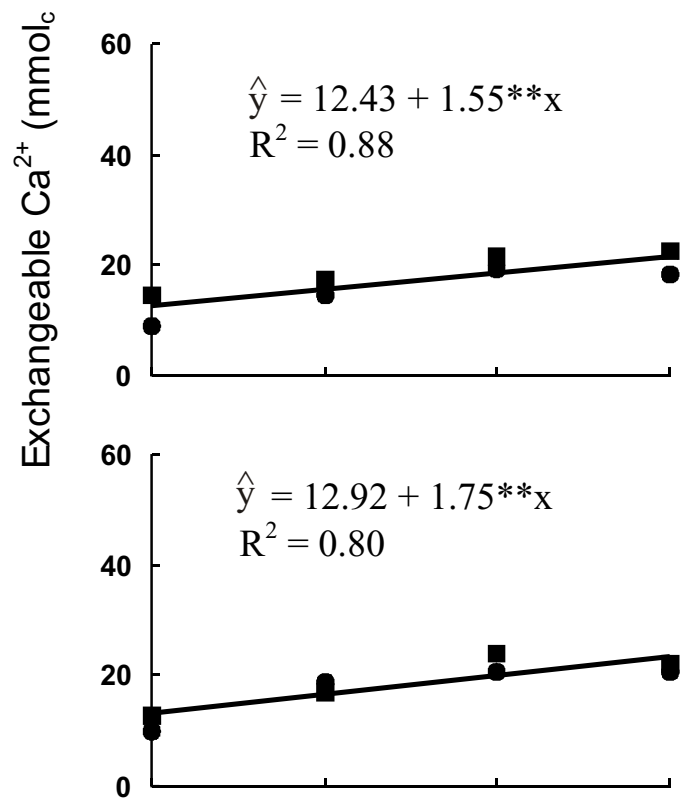

(e)

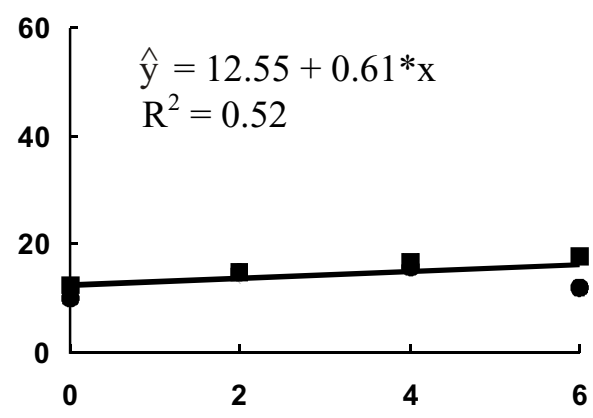

Lime $\left(\mathrm{Mg} \mathrm{ha}^{-1}\right)$

Figure 1 - Changes in soil $\mathrm{pH}$ and base saturation for different depths: 0-5 cm (a), 5-10 cm (b), 10-20 cm (c), 20-40 cm (d), and 40-60 $\mathrm{cm}(\mathrm{e})$, as a fuction of surface liming rates, after $9 \mathrm{yr}$, without $(\bullet)$ and with (ש) surface re-liming at the rate of $3 \mathrm{Mg}^{-1}$, after $2 \mathrm{yr}$, in a no-till system. *: $p<0.05$, and $* *: p<0.01$. 


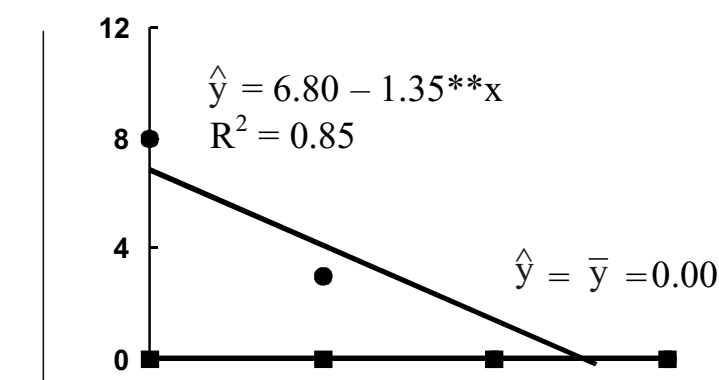

(a)

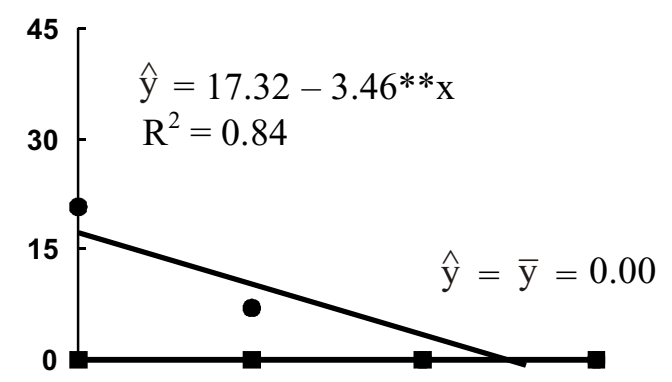

(b)

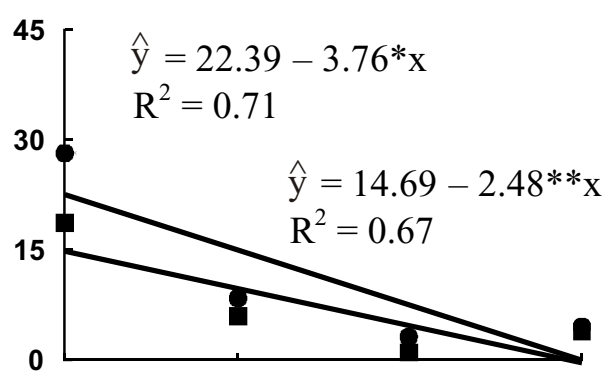

(c)
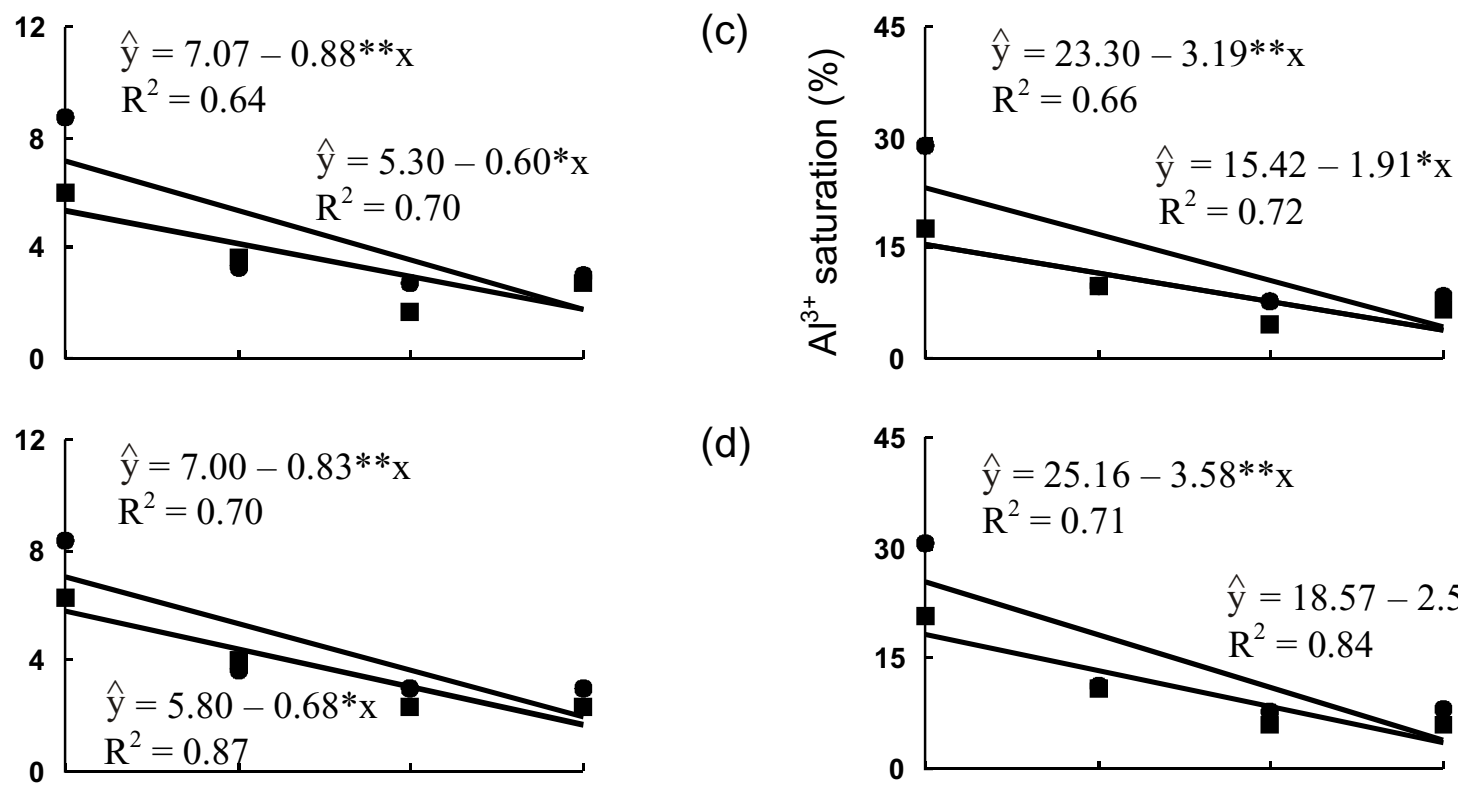

(d)
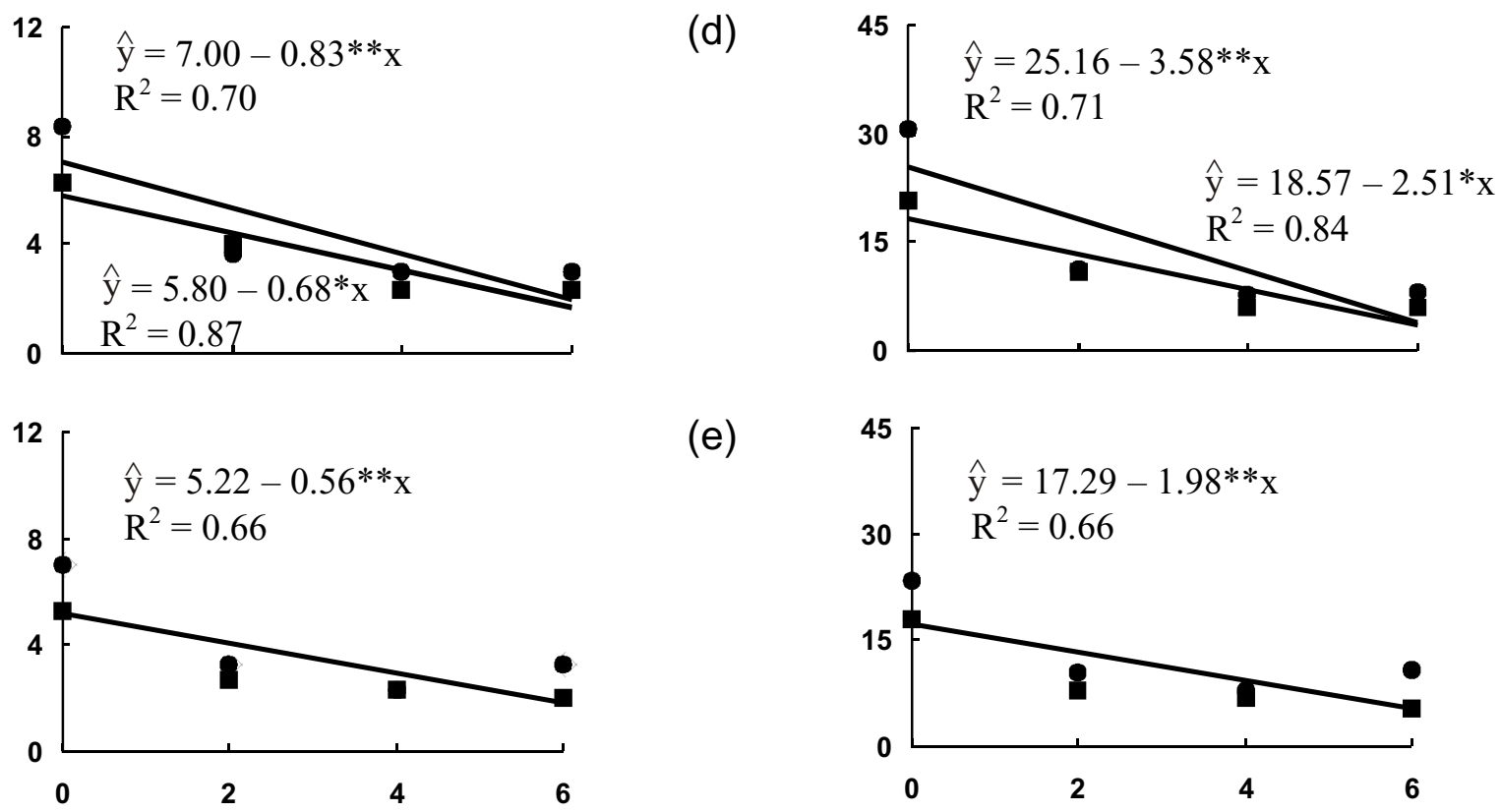

(e)

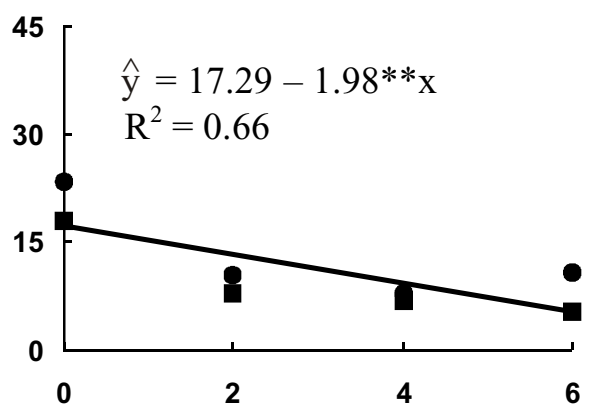

Lime $\left(\mathrm{Mg} \mathrm{ha}^{-1}\right)$

Figure 2 - Changes in soil exchangeable $\mathrm{Al}^{3+}$ and $\mathrm{Al}^{3+}$ saturation for different depths: $0-5 \mathrm{~cm} \mathrm{(a),} \mathrm{5-10} \mathrm{cm} \mathrm{(b),} \mathrm{10-20} \mathrm{cm} \mathrm{(c),} \mathrm{20-40} \mathrm{cm}$

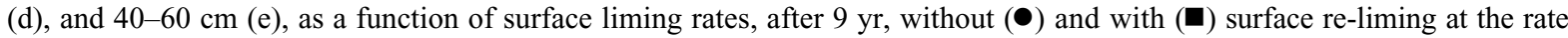
of $3 \mathrm{Mg} \mathrm{ha}^{-1}$, after $2 \mathrm{yr}$, in a no-till system. $*: p<0.05$, and $* *: p<0.01$. 
limit values of 16 to $20 \%$ of $\mathrm{Al}^{3+}$ saturation for soybean genotypes with such tolerance to acidity. Therefore, it was expected to obtain positive response from the soybean root system, mainly below the $0-5 \mathrm{~cm}$ soil depth, with the reduction of $\mathrm{Al}^{3+}$ saturation by liming. Absence of the Al toxic effect for the soybean root growth was also observed by Caires et al. (2001) and could be associated with increased organic matter content in the upper few soil centimeters under NT.

Lima et al. (2003) found that the $\mathrm{Al}^{3+}$ toxic effect for the soybean crop was lower in a clayey soil with high organic matter content $\left(53 \mathrm{~g} \mathrm{dm}^{-3}\right)$ than in

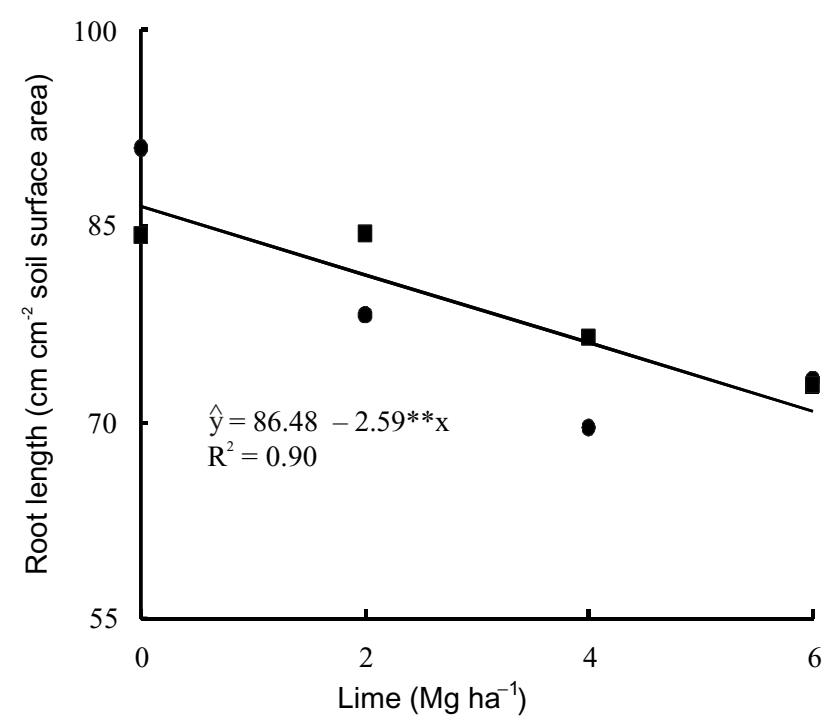

Figure 3 - Soybean root length per unit soil surface area to a depth of $60 \mathrm{~cm}$ as affected by surface liming rates, without $(\bullet)$ and with $(\mathbf{\square})$ surface re-liming at the rate of $3 \mathrm{Mg} \mathrm{ha}^{-1}$, in a no-till system. Mean of two soybean crops (2001-2002 and 2002-2003). ${ }^{* *}: p<0.01$. a sandy soil with low organic matter content $\left(8 \mathrm{~g} \mathrm{~kg}^{-1}\right)$, in spite of the clayey soil displaying an exchangeable $\mathrm{Al}^{3+}$ level 2.5 times higher than the sandy soil. Aluminum in soil solution from NT systems is largely associated with organic ligands of high molecular mass because of increased organic matter (Cambri, 2004). Since the formation of Al-organic complexes decreases Al toxicity, soybean root growth was not affected by Al concentrations in solution from NT soil (Anghinoni \& Salet, 1998). This explains why there was low toxicity of $\mathrm{Al}$ for soybean root growth (Figure 3) in an acidic soil with toxic levels of exchangeable $\mathrm{Al}^{3+}$ (Figure 2).

The relative length of roots was influenced on a quadratic form at the soil surface layer $(0-10 \mathrm{~cm})$ and also at the subsoil $(20-60 \mathrm{~cm})$ with liming rates (Figure 4). There was a higher concentration of soybean roots at the soil surface layer in relation to the subsoil layer on both plots without lime and with the highest lime rate $\left(6 \mathrm{Mg} \mathrm{ha}^{-1}\right)$. Surface re-liming at 3 $\mathrm{Mg} \mathrm{ha}^{-1}$ did not influence the distribution of soybean roots to the depth of $60 \mathrm{~cm}$. Caires et al. (2002) also verified a higher concentration of corn roots on a higher acidity in the NT soil surface layer, and that the liming improved the distribution of the root system in the soil profiles.

The nutrient levels in the leaves were adequate for the soybean crop (Malavolta et al., 1997), independently of the liming treatments (Table 1). Surfaceapplied lime increased the $\mathrm{Ca}$ and $\mathrm{Mg}$ concentrations and reduced the $\mathrm{Mn}$ concentration in both soybean roots and leaves. There was also an increase of $\mathrm{K}$ in soybean roots with lime rates and a reduction of $\mathrm{Zn}$ in soybean leaves with lime rates and re-liming. The increase in the concentrations of $\mathrm{Ca}$ and $\mathrm{Mg}$ in the soy- (a)

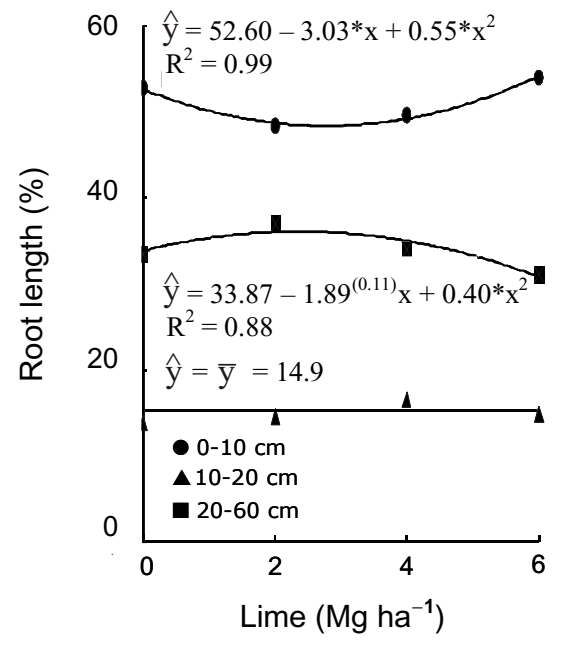

(b)

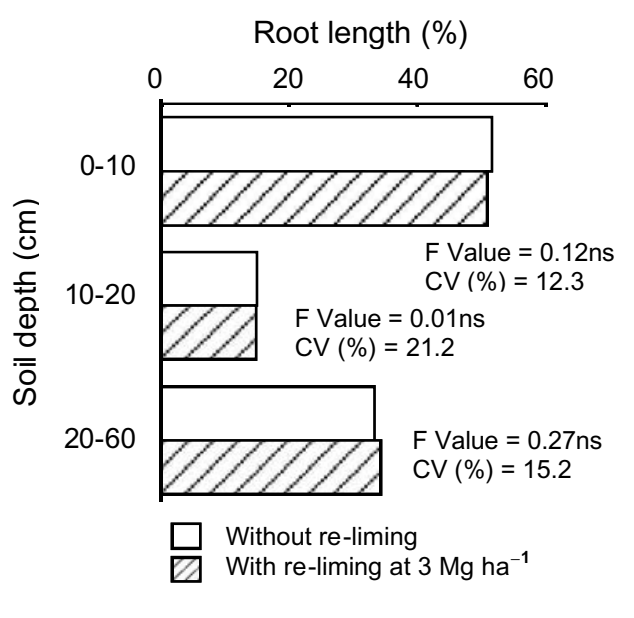

Figure 4 - Soybean relative root length for different soil depths as affected by surface liming rates (a) and surface re-liming at the rate of $3 \mathrm{Mg} \mathrm{ha}^{-1}(\mathrm{~b})$, in a no-till system. Mean of two soybean crops (2001-2002 and 2002-2003). ns: non-significant, and *: $p<0.05$. 
Table 1 - Influence of surface liming rates and surface re-liming at the rate of $3 \mathrm{Mg} \mathrm{ha}^{-1}$ on nutrient and aluminum concentrations in roots and leaves of soybean grown in a no-till system in 2002-2003.

\begin{tabular}{|c|c|c|c|c|c|c|c|c|c|}
\hline Treatment & $\mathrm{N}$ & $\mathrm{P}$ & $\mathrm{K}$ & $\mathrm{Ca}$ & $\mathrm{Mg}$ & $\mathrm{S}$ & $\mathrm{Zn}$ & $\mathrm{Mn}$ & $\mathrm{Al}$ \\
\hline & \multicolumn{6}{|c|}{ 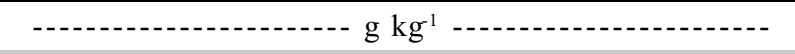 } & \multicolumn{3}{|c|}{ 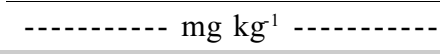 } \\
\hline Lime $\left(\mathrm{Mg} \mathrm{ha}^{-1}\right)$ & \multicolumn{9}{|c|}{ Roots } \\
\hline 0 & - & 1.0 & 5.9 & 32.1 & 3.4 & 0.7 & 89.7 & 39.5 & $7,888.7$ \\
\hline 2 & - & 0.8 & 6.2 & 32.8 & 3.6 & 0.7 & 101.7 & 35.8 & $7,500.0$ \\
\hline 4 & - & 1.0 & 6.1 & 32.8 & 3.6 & 0.7 & 92.8 & 34.0 & $7,526.7$ \\
\hline 6 & - & 0.8 & 6.0 & 33.5 & 3.7 & 0.6 & 90.1 & 29.1 & $6,976.7$ \\
\hline Effect & - & ns & $\mathrm{Q}^{*}$ & $\mathrm{~L}^{* *}$ & $\mathrm{~L}^{* *}$ & ns & ns & $\mathrm{L}^{* *}$ & ns \\
\hline CV $(\%)$ & - & 17.5 & 2.8 & 2.0 & 2.7 & 26.8 & 19.7 & 13.8 & 19.0 \\
\hline \multicolumn{10}{|l|}{ Reapplication of lime } \\
\hline Without re-liming & - & 0.9 & 6.1 & 32.5 & 3.5 & 0.7 & 93.7 & 36.2 & $7,035.0$ \\
\hline With re-liming at $3 \mathrm{Mg} \mathrm{ha}^{-1}$ & - & 0.9 & 6.0 & 33.1 & 3.7 & 0.7 & 93.4 & 33.0 & $7,910.0$ \\
\hline F Value & - & $2.6 \mathrm{~ns}$ & $0.8 \mathrm{~ns}$ & $6.2 *$ & $34.6 * *$ & $0.4 \mathrm{~ns}$ & $0.0 \mathrm{~ns}$ & $4.3 \mathrm{~ns}$ & $2.2 \mathrm{~ns}$ \\
\hline CV (\%) & - & 12.1 & 3.4 & 2.0 & 3.1 & 21.0 & 14.1 & 11.1 & 19.3 \\
\hline Lime $\left(\mathrm{Mg} \mathrm{ha}^{-1}\right)$ & \multicolumn{9}{|c|}{ Leaves } \\
\hline 0 & 59.0 & 3.9 & 15.2 & 6.7 & 3.8 & 2.2 & 53.2 & 76.3 & 105.0 \\
\hline 2 & 58.8 & 3.7 & 15.0 & 7.2 & 4.1 & 2.2 & 50.5 & 60.5 & 74.3 \\
\hline 4 & 61.9 & 3.8 & 14.4 & 7.5 & 4.2 & 2.1 & 48.0 & 57.5 & 105.5 \\
\hline 6 & 59.5 & 3.8 & 13.9 & 7.8 & 4.3 & 2.0 & 48.0 & 56.3 & 115.0 \\
\hline Effect & ns & ns & ns & $\mathrm{L}^{* *}$ & $\mathrm{~L}^{* *}$ & ns & $L^{*}$ & $\mathrm{~L}^{* *}$ & ns \\
\hline CV $(\%)$ & 4.5 & 12.0 & 14.1 & 5.4 & 5.4 & 15.7 & 9.2 & 9.1 & 66.3 \\
\hline \multicolumn{10}{|l|}{ Reapplication of lime } \\
\hline Without re-liming & 60.2 & 3.8 & 14.9 & 7.3 & 4.0 & 2.1 & 52.3 & 67.2 & 101.4 \\
\hline With re-liming at $3 \mathrm{Mg} \mathrm{ha}^{-1}$ & 59.5 & 3.8 & 14.3 & 7.4 & 4.2 & 2.1 & 47.5 & 58.1 & 98.5 \\
\hline F Value & $0.5 \mathrm{~ns}$ & $0.04 \mathrm{~ns}$ & $1.0 \mathrm{~ns}$ & $2.5 \mathrm{~ns}$ & $10.6^{*}$ & $0.3 \mathrm{~ns}$ & $6.8^{*}$ & $24.6^{* *}$ & $0.01 \mathrm{~ns}$ \\
\hline CV (\%) & 4.5 & 11.0 & 10.0 & 3.2 & 4.7 & 14.3 & 9.0 & 7.2 & 64.2 \\
\hline
\end{tabular}

$\mathrm{Q}$ and L: quadractic and linear effect by polynomial regression. ns: non-significant, $*: p<0.05$, and $* *: p<0.01$.

bean plant is related with a higher availability of exchangeable $\mathrm{Ca}^{2+}$ and $\mathrm{Mg}^{2+}$ in the soil due to dolomitic lime application (Caires et al., 2001). The decrease in the concentrations $\mathrm{Zn}$ and $\mathrm{Mn}$ in soybean is caused by their lower availability in the soil due to $\mathrm{pH}$ increase by liming (Caires \& Fonseca., 2000). The Al concentration was higher in the soybean roots than in the leaves, in agreement with Mengel \& Kirkby (2001). There were no changes in Al concentrations in the soybean roots and leaves (Table 1), despite the reduction in the exchangeable $\mathrm{Al}^{3+}$ and $\mathrm{Al}^{3+}$ saturation levels in the soil with liming treatments (Figure 2).

Soybean grain yield was not influenced by surface liming. The mean yields of the two soybean crops were $3754,3659,3667$, and $3640 \mathrm{~kg} \mathrm{ha}^{-1}$ of grains, for the surface-applied lime at the rates of $0,2,4$, and $6 \mathrm{Mg} \mathrm{ha}^{-1}$, and 3708 and $3652 \mathrm{~kg} \mathrm{ha}^{-1}$ of grains, for the treatments with and without surface re-liming at $3 \mathrm{Mg} \mathrm{ha}^{-1}$, respectively. These results are common for acidic soils under NT systems without rainfall limita- tion during the growing cycle of soybeans in Southern Brazil (Caires et al., 1998, 2003, 2006a; Pottker \& Ben, 1998; Moreira et al., 2001). When water in the topsoil is available in a NT system, soybean grain yield is not influenced by surface liming because of decreased Al toxicity for root growth (Anghinoni \& Salet, 1998) due to the formation of Al-organic complexes (Nolla \& Anghinoni, 2006) and even because root growth is stimulated by soil acidity stress.

\section{ACKNOWLEDGEMENTS}

To CNPq and to CAPES for providing scholarships to the authors.

\section{REFERENCES}

ALLEONI, L.R.F.; CAMBRI, M.A.; CAIRES, E.F. Atributos químicos de um Latossolo de cerrado sob plantio direto, de acordo com doses e formas de aplicação de calcário. Revista Brasileira de Ciência do Solo, v.29, p.923-934, 2005. 
ANGHINONI, I.; SALET, R.L. Aluminum toxicity in no tillage system in Southern Brazil. In: WORLD CONGRESS OF SOIL SCIENCE, 16., Montpellier, 1998. Proceedings. Montpellier: International Society of Soil Science, 1998. p.261267

AMARAL, A.S.; ANGHINONI, I.; HINRICHS, R.; BERTOL, I. Movimentação de partículas de calcário no perfil de um Cambissolo em plantio direto. Revista Brasileira de Ciência do Solo, v.28, p.359-367, 2004.

AZEVEDO, A.C.; KÄMPF, N.; BOHNEN, H. Alterações na dinâmica evolutiva de Latossolo Bruno pela calagem. Revista Brasileira de Ciência do Solo, v.20, p.191-198, 1996.

CAIRES, E.F.; CHUEIRI, W.A.; MADRUGA, E.F.; FIGUEIREDO, A. Alterações de características químicas do solo e resposta da soja ao calcário e gesso aplicados na superfície em sistema de cultivo sem preparo do solo. Revista Brasileira de Ciência do Solo, v.22, p.27-34, 1998.

CAIRES, E.F.; FONSECA, A.F.; MENDES, J.; CHUEIRI, W.A.; MADRUGA, E.F. Produção de milho, trigo e soja em função das alterações das características químicas do solo pela aplicação de calcário e gesso na superfície, em sistema plantio direto. Revista Brasileira de Ciência do Solo, v.23, p.315327, 1999.

CAIRES, E.F.; FONSECA, A.F. Absorção de nutrientes pela soja cultivada no sistema de plantio direto em função da calagem na superfície. Bragantia, v.59, p.213-220, 2000.

CAIRES, E.F.; BANZATTO, D.A.; FONSECA, A.F. Calagem na superfície em sistema plantio direto. Revista Brasileira de Ciência do Solo, v.24, p.161-169, 2000.

CAIRES, E.F.; FONSECA, A.F.; FELDHAUS, I.C.; BLUM, J. Crescimento radicular e nutrição da soja cultivada no sistema plantio direto em resposta ao calcário e gesso na superfície. Revista Brasileira de Ciência do Solo, v.25, p.1029-1040, 2001.

CAIRES, E.F.; BARTH, G.; GARBUIO, F.J.; KUSMAN, M.T. Correção da acidez do solo, crescimento radicular e nutrição do milho de acordo com a calagem na superfície em sistema plantio direto. Revista Brasileira de Ciência do Solo, v.26, p.10111022, 2002.

CAIRES, E.F.; BLUM, J.; BARTH, G.; GARBUIO, F.J.; KUSMAN, M.T. Alterações químicas do solo e resposta da soja ao calcário e gesso aplicados na implantação do sistema plantio direto. Revista Brasileira de Ciência do Solo, v.27, p.275-286, 2003.

CAIRES, E.F.; ALLEONI, L.R.F.; CAMBRI, M.A.; BARTH, G. Surface application of lime for crop grain production under a no-till system. Agronomy Journal, v.97, p.791-798, 2005.

CAIRES, E.F.; CHURKA, S.; GARBUIO, F.J.; FERRARI, R.A.; MORGANO, M.A. Soybean yield and quality as a function of lime and gypsum applications. Scientia Agricola, v.63, p.370379, 2006a.

CAIRES, E.F.; CORRÊA, J.C.L.; CHURKA, S.; BARTH, G.; GARBUIO, F.J. Surface application of lime ameliorates subsoil acidity and improves root growth and yield of wheat in an acid soil under no-till system. Scientia Agricola, v.63, p.502-509, 2006b.

CAMBRI, M.A. Calagem e formas de alumínio em três localidades sob sistema de plantio direto. Piracicaba: USP/ESALQ, 2004. 83p. Tese (Doutorado).

CHAN, K.Y. Using earthworms to incorporate lime into subsoil to ameliorate acidity. Communications in Soil Science and Plant Analysis, v.34, p.985-997, 2003.

CONYERS, M.K.; HEENAN, D.P.; McGHIE, W.J.; POILE, G.P. Amelioration of acidity with time by limestone under contrasting tillage. Soil \& Tillage Research, v.72, p.85-94, 2003.

COSTA, A. Doses e modos de aplicação de calcário na implantação de sucessão soja trigo em sistema plantio direto. Botucatu: UNESP/FCA, 2000. 146p. Tese (Doutorado).
ERNANI, P.R.; RIBEIRO, M.F.S.; BAYER, C. Chemical modifications caused by liming below the limed layer in a predominantly variable charge acid soil. Communications in Soil Science and Plant Analysis, v.35, p.889-901, 2004.

FRANCHINI, J.C.; MALAVOLTA, E.; MIYAZAWA, M.; PAVAN, M.A. Alterações químicas em solos ácidos após a aplicação de resíduos vegetais. Revista Brasileira de Ciência do Solo, v.23, p.533-542, 1999.

GASCHO, G.J.; PARKER, M.B. Long-term liming effects on Coastal Plain soils and crops. Agronomy Journal, v.93, p.1305-1315, 2001.

LIMA, D.V.; KLIEMANN, H.J.; FAGERIA, N.K.; MORAES, M.F.; LEANDRO, W.M.; SEVERIANO, E.C. Saturação por alumínio e relação $\mathrm{Al} / \mathrm{Ca}$ para a cultura da soja em solos de cerrado. Revista Agricultura Tropical, v.7, p.106-118, 2003.

MAlaVolta, E.; VITTI, G.C.; OLIVEIRA, S.A. Avaliação do estado nutricional das plantas: princípios e aplicações. 2.ed. Piracicaba: Associação Brasileira para Pesquisa da Potassa e do Fosfato, 1997. 319p.

MENGEL, K.; KIRKBY, E.A. Principes of plant nutrition. 5.ed. Dordrecht: Kluwer, 2001. 849p.

MIYAZAWA, M.; PAVAN, M.A.; FRANCHINI, J.C. Evaluation of plant residues on the mobility of surface applied lime. Brazilian Archives of Biology and Technology, v.45, p.251-256, 2002.

MOLONEY, M.M.; ELLIOT, M.C.; CLELAND, R.E. Acid growth effects in maize roots: evidence for a link between auxineconomy and proton extrusion in the control of root growth. Planta, v.152, p.285-291, 1981.

MOREIRA, S.G.; KIEHL, J.C.; PROCHNOW, L.I.; PAULETTI, V. Calagem em sistema de semeadura direta e efeitos sobre a acidez do solo, disponibilidade de nutrientes e produtividade de milho e soja. Revista Brasileira de Ciência do Solo, v.25, p.71-81, 2001.

MUZILLI, O.; SANTOS, D.; PALHANO, J.B.; MANETTI, J.; LANTMANN, A.F.; GARCIA, A.; CATANEO, A. Tolerância de cultivares de soja e de trigo a acidez do solo. Revista Brasileira de Ciência do Solo, v.2, p.34-40, 1978.

NOLLA, A.; ANGHINONI, I. Atividade e especiação química na solução afetadas pela adição de fósforo em latossolo sob plantio direto em diferentes condições de acidez. Revista Brasileira de Ciência do Solo, v.30, p.955-963, 2006.

OLIVEIRA, E.L.; PAVAN, M.A. Control of soil acidity in notillage system for soybean production. Soil \& Tillage Research, v.38, p.47-57, 1996.

OLMOS, I.L.J.; CAMARGO, M.N. Ocorrência de alumínio tóxico nos solos do Brasil, sua caracterização e distribuição. Ciência e Cultura, v.28, p.171-180, 1976.

PAVAN, M.A.; BINGHAM, F.T.; PRATT, P.F. Toxicity of aluminium to coffee in Ultisols and Oxisols amended with $\mathrm{CaCO}_{3}$ and $\mathrm{CaSO}_{4}$. Soil Science Society of America Journal, v.46, p.201-1207, 1982 .

PAVAN, M.A.; BLOCH, M.F.; ZEMPULSKY, H.C.; MIYAZAWA, M.; ZOCOLER, D.C. Manual de análise química do solo e controle de qualidade. Londrina: Instituto Agronômico do Paraná, 1992. 38p. (Circular, 76).

PÖTTKER, D.; BEN, J.R. Calagem para uma rotação de culturas no sistema plantio direto. Revista Brasileira de Ciência do Solo, v.22, p.675-684, 1998.

RHEINHEIMER, D.S.; SANTOS, E.J.S.; KAMINSKI, J.; XAVIER, F.M. Aplicação superficial de calcário no sistema plantio direto consolidado em solo arenoso. Ciência Rural, v.30, p.263268, 2000.

RITCHEY, K.D.; SILVA, S.E.; COSTA, V.F. Calcium deficiency in clayey B horizons of savannah Oxisols. Soil Science, v.133, p.378-382, 1982.

SALET, R.L.; ANGHINONI, I.; KOCHHANN, R. A. Atividade do alumínio na solução de solo do sistema plantio direto. Revista Científica Unicruz, v.1, p.9-13, 1999. 
SANZONOWICZ, C.; SMYTH, T.J. Effect of hydrogen on soybean root growth in a subsurface solution. Pesquisa Agropecuária Brasileira, v.30, p.255-261, 1995.

SANZONOWICZ, C.; SMYTH, T.J.; ISRAEL, D.W. Hydrogen and aluminum inhibition of soybean root extension from limed soil into acid subsurface solutions. Journal of Plant Nutrition, v. 21, p. 387-403, 1998

SILVA, M.T.B.; ANTONIOLLI, Z.I.; PETRERE, C.; BIANCHI, M.A.; GIRACCA, E.M.N. Influência de larvas de Dilobderus abderus (STURM) na densidade de organismos e características químicas do solo. Revista Brasileira de Ciência do Solo, v.21, p. 347-351, 1997 .
TENNANT, D. A test of a modified line intersect method of estimating root length. Journal of Ecology, v.63, p.995-1001, 1975.

Received October 18, 2007

Accepted February 02, 2008 